\title{
MORPHOLOGY OF THE SYMMETRICAL MORPHOTYPES OF CENTRONELLA REICHELTII VOIGT (FRAGILARIACEAE, BACILLARIOPHYCEAE) FROM PATAGONIAN ENVIRONMENTS
}

\section{MORFOLOGIA DE LOS MORFOTIPOS SIMETRICOS DE CENTRONELLA REICHELTII VOIGT (FRAGILARIACEAE, BACILLARIOPHYCEAE) DE AMBIENTES PATAGONICOS}

\author{
Ricardo O. Echenique \& José M. Guerrero \\ Departamento Científico Ficología, Facultad de Ciencias Naturales y Museo, Universidad Nacional de La Plata. Paseo \\ del Bosque s/nº, 1900 La Plata, Argentina. E-mail: rechen@museo.fcnym.unlp.edu.ar
}

\begin{abstract}
The ultrastructure of symmetrical valves of Centronella reicheltii Voigt, resembling the former C. rostafinskii Woloszynska, is studied for the first time, and their morphology is compared with the asymmetrical forms. Valve morphology and morphometry of both morphotypes are similar and only differ in the shape and striation pattern of the valve centre and the arrangement of the arm bases. However, since they occur in environments with different trophic status, the new combination C. reicheltii f. rostafinskii is proposed for the symmetrical valves, because this distinction may provide ecologically useful information.
\end{abstract}

KEYwords: Trophic status, diatoms, taxonomy, morphological variability, ultrastructure.

\section{RESUMEN}

En el presente trabajo se estudia por primera vez la ultraestructura de las valvas simétricas de Centronella reicheltii Voigt, que recuerdan a las originalmente descriptas como C. rostafinskii Woloszynska, y se compara su morfología con la de las formas asimétricas. La morfología y morfometría de las valvas de ambos morfotipos son similares y sólo se diferencian por la forma y patrón de estriación del centro valvar y por la disposición de la base de los brazos. Sin embargo, dado que cada morfotipo se encuentra en ambientes de distinto nivel trófico, se propone la nueva combinación $C$. reicheltii f. rostafinskii para las valvas simétricas ya que esta distinción provee información útil desde un punto de vista ecológico.

Palabras claves: Estado trófico, diatomeas, taxonomía, variabilidad morfológica, ultraestructura.

\section{INTRODUCTION}

The genus Centronella Voigt was described by Voigt (1902) for the species $C$. reicheltii, an araphid, tri-radiate diatom with arms asymmetrical at their bases. Woloszynska (1922) described a second species, $C$. rostafinskii Woloszynska, for specimens differing from the type by the presence of a distinct discoidal centre from which radiate three arms with swollen, almost symmetrical bases. Hustedt $(1930,1932)$ rejected the taxonomic value of these characters and synonymized both species under the earlier name $C$. reicheltii. 
The validity of the genus is controversial. Schmid (1985, 1997) questioned the status of Centronella arguing that $C$. reicheltii is simply a teratological form of Fragilaria crotonensis Kitton. As the fine structure of the genus Centronella is very similar to Fragilaria Lyngbye (sensu lato), LangeBertalot in Krammer \& Lange-Bertalot (1991) transferred Centronella to Fragilaria, a genus he had defined to include several species with tripolar forms. Although Roundet al. (1990) recognized that besides the tri-radiate morphology, the characteristics of the genus Centronella where the same as Fragilaria, they still maintained separate generic status for Centronella.

While studying the diatom flora of Río Limay basin (northwestern Patagonia, Argentina) we found specimens of Centronella that, according to their valve outline, might be assigned to the species originally described as $C$. rostafinskii. Previously Ferrario et al. (1982) described similar specimens from this region as $C$. reicheltii. This contribution presents the fine structure of the Río Limay symmetrical forms to discover if any ultrastructural differences might support their taxonomic separation from the asymmetrical specimens.

\section{MATERIALS AND METHODS}

Samples used for this study were collected at different points of the Río Limay basin (39 $00^{\circ}$ to $41^{\circ} 16^{\prime} \mathrm{S}$ and $68^{\circ} 00^{\prime}$ to $71^{\circ} 58^{\prime}$ W) from April 1978 to February 1996 using a $30 \mu \mathrm{m}$ mesh plankton net and preserved with $3 \%$ formalin. Materials were cleaned according the procedures proposed by Hasle \& Fryxell (1970) to remove organic material and mounted as permanent slides with Hyrax. For comparative purposes, specimens of $C$. reicheltii (a sample resulting of the mixture of seven clones cultured by Dr. A.-M. Schmid at the Institut für Pflanzenphysiologie, Universität Salzburg, Austria) and the slides studied by Ferrario et al.(1982), were also examined.

Diatom strews were studied with light microscopy (LM) using a Wild M20 microscope and a Nikon Microphot-FX photomicroscope equipped with phase contrast optics. For scanning electron microscopy (SEM) specimens were mounted on glass stubs, coated with gold-palladium and examined using a Jeol T-100 microscope at the Servicio de
Microscopía Electrónica of the Facultad de Ciencias Naturales y Museo de La Plata.

All samples have been incorporated into the herbarium of the Departamento Científico Ficología, Facultad de Ciencias Naturales y Museo de La Plata (Argentina) and informally designated with the abbreviation LP(C) and are as follows: Arroyito Reservoir, April 1978, LP(C) 3323; Lago Huechulafquen, June 1979, LP(C) 3330; Río Collon Cura, August 1981, LP(C) 3313; E.R. Mexía Reservoir, October 1994, LP(C) 3326; Piedra del Aguila Reservoir, August 1995, LP(C) 3331, LP(C) 3332; Arroyito Reservoir, September 1995, LP(C) 3333; E.R. Mexía Reservoir, October 1995, LP(C) 3329; E.R. Mexía Reservoir, December 1995, LP(C) 3334, LP(C) 3335; Lago Lolog, February 1996, LP(C) 3336; Piedra del Aguila Reservoir, April 1996, LP(C) 3339.

Material from the Río Collon Cura, August 1981 sample is also deposited at the diatom herbarium of the Academy of Natural Sciences of Philadelphia (ANSP) as slides A-GC 26791a and AGC 26791b, and unmounted material A-Mat. \# 10299.

Environmental features of the study area have been described in Guarrera et al. (1987) and Guerrero \& Echenique (2002).

\section{RESULTS}

Observed with LM, and with SEM under low magnification, the specimens collected at Río Limay basin present a valve outline and symmetrical basis of the arms that correspond to those described by Woloszynska (1922) as C. rostafinskii (Figs 1, 2). The valve is tri-radiate, with a discoidal to subtriangular centre, 3.2 to $4.1 \mu \mathrm{m}$ in diameter, without distinct striation. The arms are 20.5-37 $\mu \mathrm{m}$ long; their length is slightly unequal, the three arms being of different length or at least one of them shorter than the other two, with differences not usually exceeding 1-2 $\mu \mathrm{m}$ and exceptionally reaching 4-6 $\mu \mathrm{m}$.

Examination of 40 specimens from a population of symmetrical valves revealed that $35 \%$ have arms with angles ranging from $118^{\circ}$ to $122^{\circ}$, $62.5 \%$ have angles radiating between $110^{\circ}$ and $128^{\circ}$ and the remaining $2.5 \%$ have greater angles of separation $\left(99^{\circ}-139^{\circ}\right)$. The arms have a swelling at 
the basis, 1.6-2.9 $\mu \mathrm{m}$ broad, and gradually taper towards capitate ends, $1.5 \mu \mathrm{m}$ broad. The striae are parallel, 22-30 in $10 \mu \mathrm{m}$ and delimit a narrow sternum or "pseudoraphe".

When examined with SEM, it can be observed that the striae are alternately arranged and composed of single rows of rounded areolae, 70-80 (exceptionally 90) in $10 \mu \mathrm{m}$, which continue onto the valve mantle. At the discoidal centre the sterna converge to an approximately central point (Fig. 3). Central striae are composed of occluded areolae "ghost striae" (Fig. 4) and show a regular pattern, similar to that of the arms (Fig. 3). In some specimens, near the central body the sternum runs closer to one margin of the valve while the opposite side is slightly more inflated, resulting in a subtle asymmetry at the swollen basis (Fig. 5). Each arm bears an apical pore field composed of 2-3 rows of pores and surrounded by a variable number of small spines (Figs 6,7). Similar spines occur near the striae at the junction of valve face and valve mantle. Small semicircular plaques, sometimes not very distinct, occur at the margin of the valve mantle (Fig. 8). Internally, only one or two arms have a rimoportula, transversely orientated relative to the apical axis (Fig. 9). The pervalvar axis is 1.7-2.4 $\mu \mathrm{m}$ long.

Table I summarizes the morphometric data (range, mean and standard deviation) of the specimens studied.
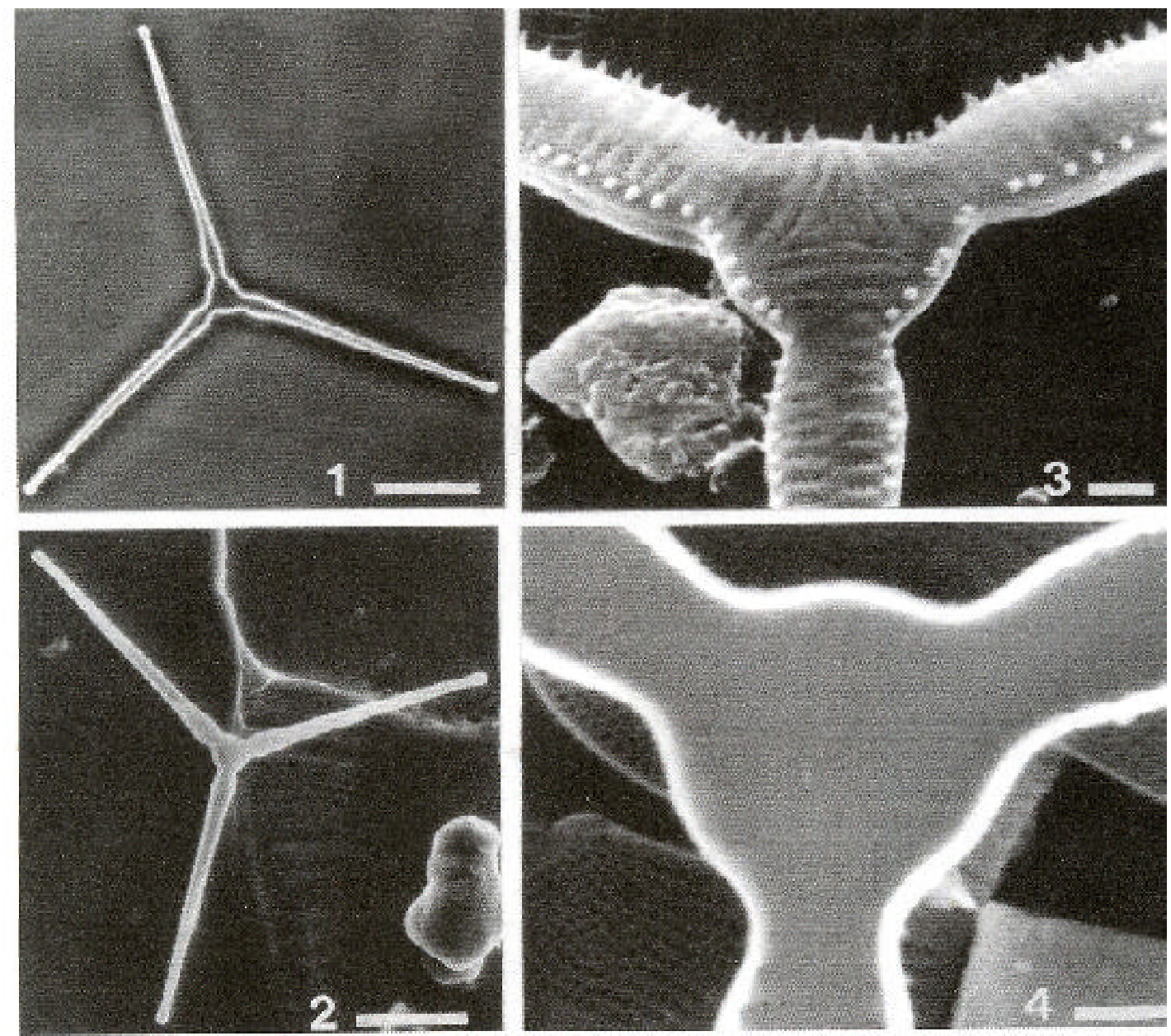

FIGUREs 1-4. Light and scanning electron micrographs of C. reicheltii f. rostafinskii (Woloszynska) comb. nov. Fig. 1. LM. Valve view. Figs 2-4. SEM. Fig. 2. External valve view. Fig. 3. Detail of valve centre in external view. Fig. 4. Detail of valve centre in internal view. Scale bars: Figs $1,2=10 \mu \mathrm{m}$; Figs 3, $4=1 \mu \mathrm{m}$. 

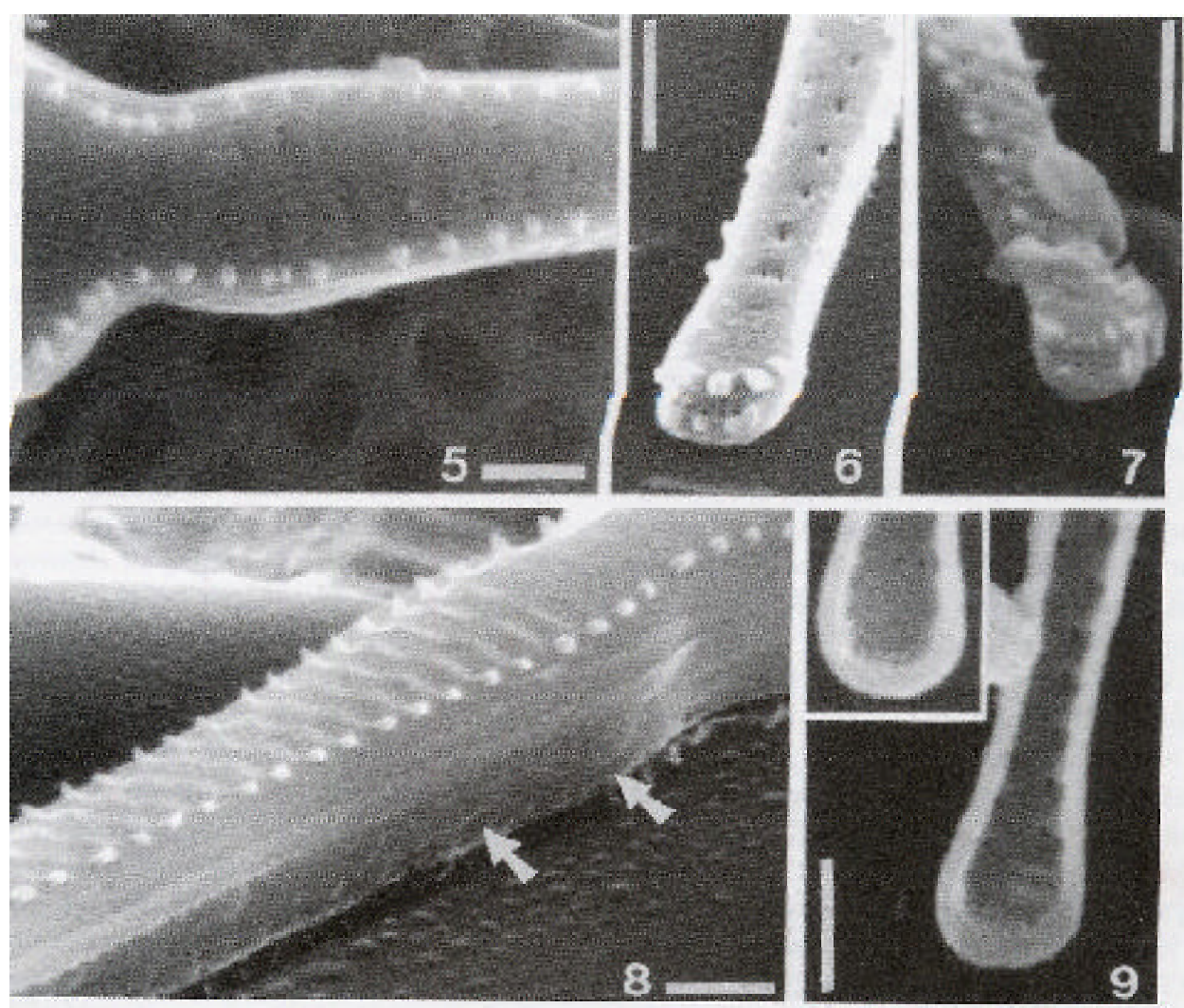

FIGURES 5-9. Scanning electron micrographs of C. reicheltii f. rostafinskii (Woloszynska) comb. nov. Fig. 5. External view of the arm basis, showing striae and spine arrangement. Figs 6, 7. External view of the arm apex showing apical pore fields. Fig. 8. External view of an arm showing semicircular plaques (arrows). Fig. 9. Internal view of arm apex with rimoportula. Inset: Internal view of arm apex without rimoportula. Scale bars $=1 \mu \mathrm{m}$.

TABLE I. Morphometric data for (Woloszynska) comb. nov.

\begin{tabular}{|c|c|c|c|c|c|c|}
\hline & \multicolumn{2}{|c|}{ Arm length } & \multicolumn{4}{|c|}{ Angles between arms } \\
\hline & shortest (1) & median (2) & longest (3) & $1-2$ & $2-3$ & $3-1$ \\
\hline Maximum & 33.3 & 34.7 & 37.0 & 123.0 & 139.0 & 128.0 \\
\hline Minimum & 20.5 & 22.0 & 22.0 & 99.0 & 118.0 & 114.0 \\
\hline Mean & 26.4 & 27.3 & 28.1 & 16.8 & 120.9 & 122.3 \\
\hline \multirow[t]{2}{*}{ St. Deviation } & 2.77 & 2.91 & 3.02 & 3.93 & 3.21 & 2.89 \\
\hline & $\begin{array}{l}\text { Arm basis } \\
\text { width }\end{array}$ & $\begin{array}{l}\text { Central body } \\
\text { diameter }\end{array}$ & $\begin{array}{l}\text { Striae } \\
\text { in } 10 \mu \mathrm{m}\end{array}$ & \multicolumn{3}{|c|}{$\begin{array}{l}\text { Areolae } \\
\text { in } 10 \mu \mathrm{m}\end{array}$} \\
\hline Maximum & 2.9 & 4.1 & 30.0 & \multicolumn{3}{|c|}{90.0} \\
\hline Minimum & 1.6 & 3.2 & 22.5 & \multicolumn{3}{|c|}{70.0} \\
\hline Mean & 2.2 & 3.8 & 26.5 & \multicolumn{3}{|c|}{77.9} \\
\hline St. Deviation & 0.24 & 0.26 & 2.28 & \multicolumn{2}{|c|}{4.79} & \\
\hline
\end{tabular}




\section{DISCUSSION}

The fine structure of the asymmetrical valves of $C$. reicheltii (morphotype reicheltii), both in natural populations and cultivated clones, has been described by Schmid (1978, 1985, 1997), whereas Marvan \& Hindak (1989) carried out a detailed study of the valve morphometry. We illustrate here our SEM micrographs of specimens present in Dr. A.M. Schmid's sample resulting from the mixed clones of C. reicheltii (Figs 10-14) to facilitate discussion of the differences observed in relation to our symmetrical valves resembling the species $C$. rostafinskii (morphotype rostafinskii). Table II summarizes the morphometric data, geographic distribution and available ecological information of C. rostafinskii and C. reicheltii.

Although we consulted several herbaria (Academy of Natural Sciences of Philadelphia, USA; Natural History Museum, UK; Alfred-WegenerInstitute für Polar-und Meeres-forschung, Germany and Polska Akademia Nauk-Instytut Botaniki, Poland) we were unable to find type material of $C$. rostafinskii. The holotype was lost during World War II (J. Sieminska, pers. comm.).

Comparison of both morphotypes shows that they have a similar type of striae and areolae, apical pore fields and presence of semicircular plaques along the edge of valve mantle as well as type and distribution of spines (Figs 11-13). Ranges of the main morphometric characters (length and breadth of arms, striae and areolae density) measured by us and given by different authors for the two species also overlap. The morphological differences observed are restricted to the morphology and striation pattern of the valve centre. In contrast to morphotype rostafinskii, morphotype reicheltii lacks a definite discoidal centre and the central area formed by the union of the three arms is irregularly shaped; each arm basis is bent with a deep incision on one side and a flexure on the opposite one, resulting in a marked asymmetry (Fig. 10). This area is ornamented by "ghost striae" randomly arranged (Figs 11, 12). According to Schmid (1985), "striae run in a chaotic manner through the central field. Very often the pseudoraphe can be seen running, together with its striae, continuously from $1 \mathrm{arm}$ into another, whereas the pseudoraphe from the third arm ends blindly, or all 3 pseudoraphes end in a randomly structured area". However, in our specimens the "ghost striae" pattern is always regular and continuous with that of the arms such that the sterna of the three arms join approximately at the middle point of the discoidal centre. Examination of the specimens from the Río Limay basin material suggests that this morphology remains fairly constant and no transitional forms to the morphotype reicheltii have been observed.

When examining specimens of the morphotype reicheltii present in the mix of clones with SEM, we observed one valve exhibiting a somewhat triangular central body (Fig. 14), which might be considered an intermediate form between morphotype reicheltii and morphotype rostafinskii. The morphological variability of Centronella had already been pointed out by previous authors. Studying material from Poland, Wojciechowski (1967) found specimens with symmetric arms but lacking a discoidal centre; these specimens, coexisting with $C$. rostafinskii, where named as a new variety, $C$. rostafinskii var. concinna Wojciechowski. In laboratory cultures of $C$. rostafinskii, Wojciechowski found much morphological variability and even reported bipolar forms. Wysocka (1959) observed a marked variability of valve outline in natural populations of C. rostafinskii and attributed the mostly symmetrical valves to initial cells that gradually lose their symmetry in the course of successive cell divisions, although he provided no explanation of this process. Culturing C. reicheltii, Schmid (1997) obtained a wide range of morphological forms, noting a tendency of the tripolar valves to revert to bipolarity, i.e. the loss of one of the three arms ("appendixarm") by shortening in the course of progressive cell divisions or by narrowing its basal constriction until this arm is shed, followed by a restoration of the regular symmetry by correcting the valve outline, thus producing bipolar forms resembling $F$. crotonensis. Moreover, she also obtained chains of tripolar and bipolar valves, very similar to colonies of the latter species.

Besides the morphological differences noted between $C$. reicheltii and $C$. rostafinskii, the literature for Europe and South America suggest that the species' occurrences are correlated with the trophic status of the water-body (see Table II). In Central Europe, $C$. reicheltii is reported from humic, mesotrophic to eutrophic environments (Hustedt 1930, 1932, Schmid 1978, 1985; Germain 1981, 
Marvan \& Hindák 1989, Krammer \& LangeBertalot 1991) while $C$. rostafinskii is found in oligotrophic water-bodies (Wojciechowski 1964, 1967). In South America, Centronella has been recorded from oligotrophic lakes of the southern Andes in Chile and Argentine Patagonia (Thomasson 1963, Ferrarioet al. 1982). Although in both cases the specimens found are referred as C. reicheltii, their valve outline resembles that of the morphotype rostafinskii. Our specimens of the morphotype rostafinskii were collected from the same geographic region and were found in oligotrophic lakes and in oligotrophic to rather mesotrophic reservoirs.

TABLE II. Comparative morphometric data for the two morphotypes of $C$. reicheltii, environmental charactheristics and geographic distribution. References: 1- Voigt (1902); 2- Hustedt (1930);3- Wysocka (1959); 4- Schmid (1978); 5- Schmid (1985); 6- Germain (1981); 7- Marvan \& Hindák (1989); 8- Krammer \& Lange-Bertalot (1991);9- Woloszynska (1922); 10- Thomasson (1963); 11- Wojciechowski (1964); 12- Wojciechowski (1967); 13- Ferrario et al. (1982); 14- This paper.

Morphotype reicheltii

\begin{tabular}{|c|c|c|c|c|c|c|c|}
\hline References & 1 & 2 & 3 & $4-5$ & 6 & 7 & 8 \\
\hline Arm length $(\mu \mathrm{m})$ & 32 & $22-35$ & $28-30$ & $22-40$ & $20-25$ & $20-32$ & $22-40$ \\
\hline Centre diameter & - & - & $3-5$ & - & - & - & - \\
\hline Arm width (pole) & - & 1 & - & $1-2$ & - & - & - \\
\hline Arm width (basis) & 3 & 2 & $2-2.6$ & $2-3.5$ & 2 & - & 2 \\
\hline Striae in $10 \mu \mathrm{m}$ & - & $22-26$ & - & $18-24$ & $22-25$ & $19-20(?)$ & $19-26$ \\
\hline Trophic status & - & eutrophic & - & $\begin{array}{l}\text { eutrophic, } \\
\text { humic }\end{array}$ & eutrophic? & eutrophic & $\begin{array}{c}\text { mesotrophic - } \\
\text { eutrophic }\end{array}$ \\
\hline Country / Region & $\begin{array}{l}\text { Germany, } \\
\text { Switzerland }\end{array}$ & Central Europe & Poland & Austria & France & $\begin{array}{l}\text { Western } \\
\text { Slovakia }\end{array}$ & France \\
\hline
\end{tabular}

Morphotype rostafinskii

\begin{tabular}{|c|c|c|c|c|c|c|}
\hline References & 9 & 10 & 11 & 12 & 13 & 14 \\
\hline Arm length $(\mu \mathrm{m})$ & 35 & - & $35-39.2$ & $27.5-40$ & $24-26$ & $20.5-37$ \\
\hline Centre diameter & 3 & - & $3.3-4.9(?)$ & $3.7-5$ & $4.5(?)$ & (2) $3.2-4.1$ \\
\hline Arm width (pole) & - & - & - & 2 & 1.5 & 1.5 \\
\hline Arm width (basis) & $2-3$ & - & - & $2.2-4.3$ & 2.5 & $2-2.5$ \\
\hline Striae in $10 \mu \mathrm{m}$ & - & - & $19-20$ & $18-21$ & $19-21$ & $22-30$ \\
\hline Trophic status & - & oligotrophic & $\begin{array}{l}\text { oligotrophic- } \\
\text { distrophic }\end{array}$ & $\begin{array}{c}\text { para- } \\
\text { oligotrophic }\end{array}$ & oligotrophic & $\begin{array}{l}\text { oligotrophic - } \\
\text { mesotrophic }\end{array}$ \\
\hline Country / Region & $\begin{array}{l}\text { Czecho- } \\
\text { slovakia? }\end{array}$ & $\begin{array}{c}\text { Chilean } \\
\text { Patagonia }\end{array}$ & Poland & Poland & $\begin{array}{l}\text { Argentine } \\
\text { Patagonia }\end{array}$ & $\begin{array}{l}\text { Argentine } \\
\text { Patagonia }\end{array}$ \\
\hline
\end{tabular}



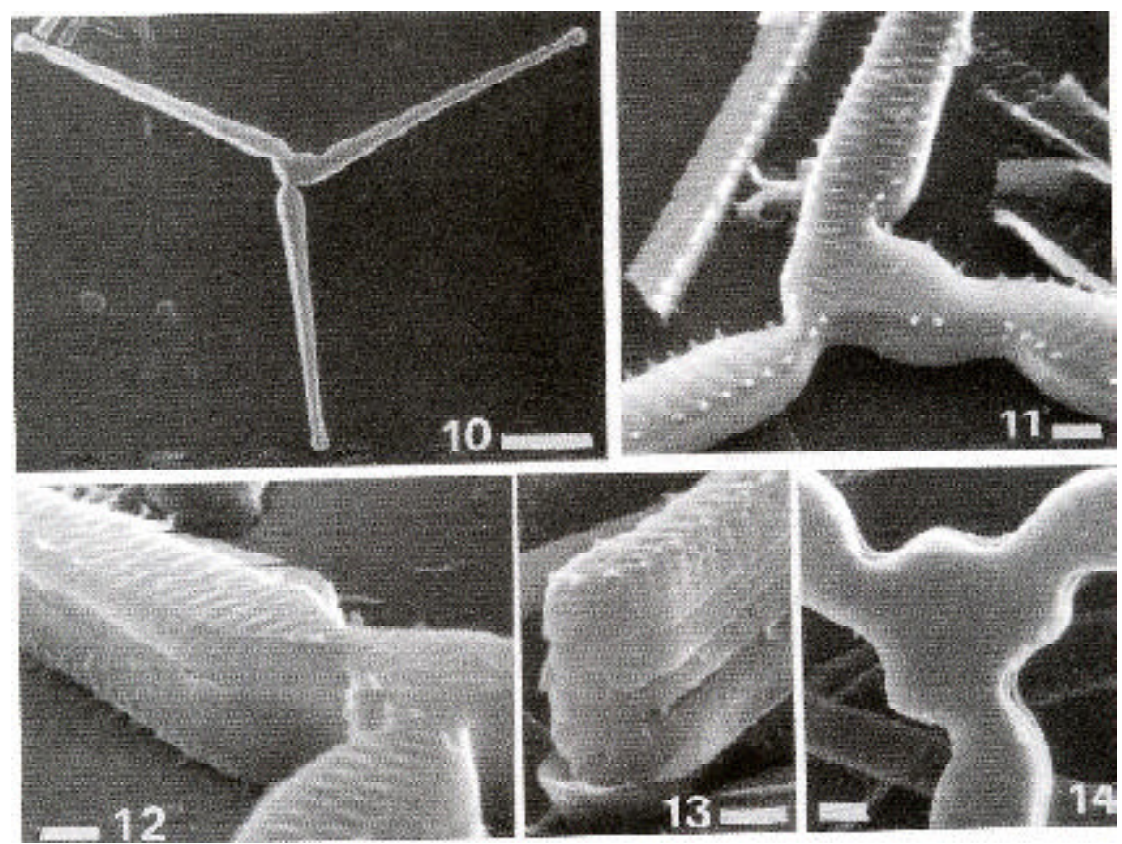

FIGURES 10-14. Scanning electron micrograph of C. reicheltii f. reicheltii. Mix of seven clones provided by Dr. A.-M. Schmid. Fig. 10. External valve view. Fig. 11. Detail of valve centre in external view. Note the chaotic arrangment of the "ghost striae". Fig. 12. Detail of valve centre in external view showing semicircular plaques (arrow). Fig. 13. External view of the arm apex showing apical pore fields. Fig. 14. External view of a frustule with a subtriangular central body. Scale bars: Fig. $10=10 \mu \mathrm{m}$; Figs $11-14=1 \mu \mathrm{m}$.

Although we did not find transitional forms between the morphotypes rostafinskii and reicheltii in our material, previous reports of morphological variability within this "genus" allow us to speculate that both forms could be the extremes of the range of the morphological variability of the same taxon, thus supporting the nomenclatural changes made by Hustedt $(1930,1932)$ at the specific level. The presence of a slight asymmetry at the swollen bases of the arms in natural populations of the morphotype rostafinskii observed in the present study as well as the great morphological variability in natural populations (Wysocka 1959) and under different culture conditions exhibited by $C$. reicheltii (Schmid 1997) and by C. rostafinskii (Wojciechowski 1967), suggest that this variability is determined largely by environmental conditions. Their occurrence in nature might be related to the trophic status of the waterbody. Schmid (1997) suggests that tripolarity in Centronella is the result of an accident during the formation of initial valves, probably caused by the combination of environmental factors, such as a high level of eutrophication and humic substances. However, since the "genus" has also been found in oligotrophic, non-humic habitats, it rather seems that eutrophic conditions induce the deformation of the valve centre to produce asymmetrical forms.

With respect to the validity of the genus Centronella, Schmid (1985) suggested that it is simply a teratological form of Fragilaria (most probably $F$. crotonensis), caused by an error during initial valve formation. Round et al. (1990) expressed surprise that such an error could give rise to almost symmetrical forms and although they recognized that no other feature had been discovered to support the separation of Centronella from Fragilaria, they maintained the generic status for Centronella suggesting that the tri-radiate shape might be "genetically fixed within an ancient lineage of 'fragilarioid' diatoms". Regardless, as mentioned above, Schmid's (1997) more recent study presents new evidence for the inclusion of Centronella within Fragilaria.

Other species of Fragilaria with tripolar valves ( $F$. construens (Ehrenberg) Grunow; $F$. pinnata Ehrenberg and $F$. leptostauron (Ehrenberg) Hustedt) have been transferred to the genera Staurosira (Ehrenberg) Williams \& Round and Staurosirella Williams \& Round (Williams \& Round 1987, Round et al. 1990). Thus, if Centronella was 
included in Fragilaria sensu stricto, it would be the only member of the genus exhibiting tripolar valves (D. Williams, pers. comm.). Until the taxonomic position of Centronella is solved and the species of Fragilaria that unequivocally gives rise to the tripolar valves is identified, we prefer to retain the genus Centronella and place the morphotype rostafinskii as a form of reicheltii: Centronella reicheltii f. rostafinskii (Wolozsynska) comb. nov., taking into account that this distinction may provide ecologically useful information. Thus:

Centronella reicheltii f. rostafinskii (Woloszynska) Echenique \& Guerrero comb. et stat. nov.

Basionym: Centronella rostafinskii Woloszynska 1922, Rozpr. Wydz. mat.-przyr. P.A.U. 62, p. 90-92, fig.1: a-b.

Since the holotype was lost during World War II (J. Sieminska, pers. comm.) we designate here a neotype:

Neotype: Slide 2, LP(C) 3313. Departamento Científico Ficología, Facultad de Ciencias Naturales y Museo, Universidad Nacional de La Plata.

\section{ACKNOWLEDGMENTS}

We are greatly indebted to Dr. Anne-Marie Schmid for kindly providing the sample of mixed clones of Centronella reicheltii cultured at the Institut für Pflanzenphysiologie, Universität Salzburg, Austria. We are also thankful to Charles W. Reimer for offering important suggestions and to David Williams for his helpful comments as reviewer of an early version of this paper. The manuscript also benefited from the constructive comments of the anonymous reviewers. We are very grateful to J. Gwynfryn Jones, Ryszard Ligowski and Jadwiga Sieminska for searching for type material of Centronella rostafinskii at their respective herbaria. Financial support was provided by Comisión de Investigaciones Científicas (Provincia de Buenos Aires, Argentina).

\section{REFERENCES}

Ferrario, M.E., M.A. D amascos \& R.O. Echenique. 1982. Nuevas citas ficológicas y una nueva variedad. Boletín de la Sociedad Argentina de Botánica 20: 169-182.
Germain, H. 1981. Flore des Diatomées. Diatomophycées eaux douces et saumâtres du Massif Armoricain et des contrées voisines d'Europe occidentale. Societé Nouvelle des Editions Boubée, Paris. 444 pp.

Guarrera, S.A., M.A Casco, R.O. Echenique \& H.A. Labollita. 1987. Las Algas del Sistema del Río Limay (Argentina) I. Cyanophyta, Chrooco-ccales y Chamaesiphonales. Revista del Museo de La Plata, Bot. 14: 163-189.

Guerrero, J.M. \& R.O. Echenique. 2002. Cyclostephanos patagonicus sp. nov., a new freshwater diatom from western Patagonia (Argentina). Diatom Research 17: 141-151.

Hasle, G.R. \& GA. Fryxell. 1970. Diatoms: cleaning and mounting for light and electron microscopy. Transactions of the American Microscopical Society 86 : 469-474.

Hustedt, F. 1930. Bacillariophyceae (Diatomeae). In: Die Süsswasser-flora Mitteleuropas. 10. (ed. A. Pascher), pp. 1-466. Fisher Verlag, Jena.

Hustedt, F. 1932. Die Kieselalgen Deutchlands, Österreichs und der Schweiz mit Berücksichtigung der übrigen Länder Europas sowie der angrezenden Meeresgebeite. In: KryptogamenFlora von Deutschland 7 (ed. L. Rabenhorst), pp. 177-320. Akademische Verlagsgeselschaft M.B.H., Leipzig.

Krammer, K. \& H. Lange-bertalot. 1991. Bacillariophyceae. 3: Centrales, Fragilariaceae, Eunotiaceae. In: Süsswasserflora von Mitteleuropa Bd 2. (eds. H. Ettl, J. Gerlof, H. Heynig \& D. Mollenhauer), pp. 1-576. Fisher Verlag Stuttgart, Jena.

Marvan, P. \& F. Hindak. 1989. Morphologische Variabilität von Centronella reicheltii (Bacillariophyceae) aus der Westlowakei. Preslia 61: 1-14

Round, F.E., R.M. Crawford \& D.G. Mann. 1990. The diatoms. Biology and morphology of the genera. Cambridge University Press, Cambridge. 747 pp.

Schмid, A.M. 1978. Zur Diatomeenflora Salzburgs. I. Centronella reichelti Voigt (Fragilariaceae) - Neu für Österreich. Floristische Mitteilungen aus Salzburg 5: 9-17.

Schmid, A-M. 1985. Centronella reichelti Voigt - A very unusual diatom in the surface sediments of the Grabansee. In: Contribution to the Paleolimnology of the Trumer Lakes (Salzburg) and the Lakes Mondsee, Attersee and Traunsee (upper Austria). (eds. D.R. Danielopol, R. Schmidt \& E. Schultze). Österreichische Akademie der Wissenschaften: 65-78.

Schmid, A-M. 1997. Intraclonal variation of tripolar pennate diatom "Centronella reicheltii" in culture: strategies of reversion to the bipolar Fragilaria-form. Nova Hedwigia 65: 27-45.

Thomasson, K. 1963. Araucanian lakes. Acta Phytogeographica Suecica 47: 1-139. 
Voigt, M. 1902. Neue Organismen aus Plöner Gewässern.Forschungsberichte aus der Biologischen Station zu Plön 9: 33-46.

Williams, D.M. \& F.E. Round. 1987. Revision of the genus Fragilaria. Diatom Research 2: 267-288.

Wojciechowski, I. 1964. Nowe stanowisko Centronella reichelti Voigt na Pojezierzu L'ecynskoWlodawskim (Lubelszyzna) - New habitat of Centronella reichelti Voigt in the lake-land situated between L'eczna and Wlodawa (in the region Lublin). Fragmenta Floristica et Geobotanica. 10: 283-285.
WojCIECHowski, I. 1967. Centronella rostafinskii Wolosz. aus Seen im Lubliner Land (Polen). Schweizerische Zeitschrift Hydrologie 29: 311-332.

Woloszynska, J. 1922. Nowy gatunek okrzemky Centronella rostafinskii $\mathrm{n}$. sp. oraz spis roslin planktonowych jezior: Firlejowskiego i Kunowskiego. Rozprawy wydzialu matematyczno-przyrodniszego Polskiej. Akademii umiejetnosci 62: 89-92.

Wysocka, H. 1959. On the Morphology and Biology of Centronella reicheltii Voigt. Acta Societatis Botanicorum Poloniae 28: 263-275. 